\title{
Stimulation of the Differential Rate of Exoenzyme Formation in Bacillus amyloliquefaciens by Streptolydigin, an Inhibitor of RNA Chain Elongation
}

\author{
By G. COLEMAN AND D. A. STORMONTH \\ Department of Biochemistry, Nottingham University Medical School, \\ Nottingham $N_{7} 2 R D$
}

(Received 13 September 1974)

INTRODUCTION

Bacillus amyloliquefaciens secretes a number of degradative enzymes into the external environment. A low level of extracellular enzymes occurs during the exponential phase of growth, then the rate of enzyme secretion increases to a high linear value which is maintained into the stationary phase (Coleman, 1967).

A model to account for these characteristics involves two separate effects, which may be superimposed; both would contribute to increased exoprotein mRNA formation and hence exoprotein itself. The first is an increase in RNA polymerase available for exoenzyme gene transcription on cessation of ribosomal RNA synthesis, after the end of exponential growth. The second is an increase in the concentration of the substrate for this enzyme resulting from ribosomal RNA turnover during the post-exponential phase of the growth cycle (Coleman, Brown \& Stormonth, 1974). If the proposed model is correct, it might be possible to separate these two effects. Therefore the effect on $B$. amyloliquefaciens of a number of inhibitors of RNA synthesis; including streptolydigin, was examined. Streptolydigin specifically inhibits the rate of transcription by reducing the rate of phosphodiester bond formation during RNA chain elongation without affecting the initiation or termination processes (Cassani, Burgess, Goodman \& Gold, 197I).

\section{METHODS}

Organism. The aerobic spore-forming bacillus used in this work was Bacillus amyloliquefaciens strain T (Welker \& Campbell, 1967).

Growth conditions. The composition of the medium was: $\left(\mathrm{NH}_{4}\right)_{2} \mathrm{HPO}_{4}, 34 \mathrm{mM} ; \mathrm{KCl}$, $5 \mathrm{~mm} ; \mathrm{MgSO}_{4}, \mathrm{I} \mathrm{mM} ; \mathrm{FeCl}_{3}, 0.5 \mathrm{~mm} ; \mathrm{CaCl}_{2}, 0.125 \mathrm{~mm} ; \mathrm{ZnSO}_{4}, 0.0125 \mathrm{~mm}$; sodium citrate, 2. I $25 \mathrm{~mm}$; 'trace metal ion' solution (Coleman \& Elliott, 1965), 0.25 ml/1; vitamin solution, $50 \mathrm{ml} / \mathrm{l}$; a mixture of equal amounts (by weight) of 19 naturally-occurring L-amino acids (cysteine omitted) to give a total amino acid concentration of $0.5 \%$; maltose, $\mathrm{I} \%(\mathrm{w} / \mathrm{v})$. The medium was adjusted to $\mathrm{pH} 7.2$ with $10 \%(\mathrm{v} / \mathrm{v})$ phosphoric acid. The vitamin solution consisted of $0 . \mathrm{I} \mathrm{mg}$ riboflavin, and $\mathrm{I} \cdot \mathrm{O} \mathrm{mg}$ each of inositol, biotin, choline chloride, folic acid, nicotinamide, calcium pantothenate, pyridoxal-5-phosphate and thiamine hydrochloride in I 1 water. Batches $(50 \mathrm{ml})$, contained in $250 \mathrm{ml}$ conical flasks, were loop-inoculated from an aqueous spore suspension. The cultures were incubated at $30{ }^{\circ} \mathrm{C}$ in a gyrotory incubator-shaker (Model G25, New Brunswick Scientific Co., New Brunswick, New Jersey, U.S.A.).

Washed bacterial suspension experiments. Late exponential phase cultures $(20 \mathrm{~h})$ were centrifuged at $5000 \mathrm{~g}$ for $2 \mathrm{~min}$ and the supernatant fraction was discarded. The bacterial 
Table I. Effect of streptolydigin on Bacillus amyloliquefaciens

\begin{tabular}{|c|c|c|}
\hline \multicolumn{3}{|c|}{ Standard deviations are given in parentheses } \\
\hline & $\begin{array}{c}\text { No } \\
\text { streptolydigin }\end{array}$ & $\begin{array}{l}\text { Streptolydigin } \\
\quad\left(10^{-5} \mathrm{M}\right)\end{array}$ \\
\hline $\begin{array}{l}\text { Differential rate of } \\
\text { enzyme formation } \\
\text { (units formed/mg } \\
\text { dry wt increase } \\
\text { in bacterial mass) }\end{array}$ & & \\
\hline$\alpha$-Amylase & $4(0.5)$ & $10(1)$ \\
\hline Protease & $40(4)$ & $70(8)$ \\
\hline Ribonuclease & $8(1)$ & $18(2)$ \\
\hline $\begin{array}{l}\text { 'Nucleotide' pool } \\
\text { size }(\mu \mathrm{g} / \mathrm{mg} \text { cell } \\
\text { material })\end{array}$ & $6.1 \quad(0.4)$ & $11.0 \quad(0.7)$ \\
\hline $\begin{array}{l}\text { Rate of increase in } \\
\text { bacterial density } \\
\text { (mg dry wt/ml culture/h) }\end{array}$ & $0.42(0.02)$ & $0.25(0.01)$ \\
\hline
\end{tabular}

pellet was washed by resuspension in fresh growth medium and then resuspended to the original density in the same medium, which was maintained at $30{ }^{\circ} \mathrm{C}$ to prevent the bacteria from suffering a temperature shock, in the presence and absence of $\mathrm{IO}^{-5} \mathrm{M}$-streptolydigin (a gift from the Upjohn Co., Kalamazoo, Michigan, U.S.A.). The resulting suspensions were then incubated with shaking $\left(50 \mathrm{ml} / 250 \mathrm{ml}\right.$ conical flask) at $30^{\circ} \mathrm{C}$, and samples taken for assay at $30 \mathrm{~min}$ intervals.

Extracellular enzyme assay. $\alpha$-Amylase, protease and ribonuclease were determined in bacterial suspension supernatant fractions as described by Coleman \& Elliott (I962), May \& Elliott (1968) and Coleman \& Elliott (1965), respectively.

Bacterial density determination. Bacterial densities were determined by the method of Stormonth \& Coleman (1972).

'Nucleotide' pool size. This was measured as described by Stormonth \& Coleman (1974).

\section{RESULTS}

Late exponential phase bacteria were resuspended in fresh I \% maltose- $0.5 \% \mathrm{~L}$-amino acid mixture defined medium and increase in bacterial density, exoenzyme secretion and 'nucleotide' pool size were monitored during incubation in the presence and absence of streptolydigin.

It was found that in the presence of streptolydigin at a concentration of $1 \mathrm{O}^{-5} \mathrm{M}$ the bacteria continued to grow at a constant rate which was, however, only $60 \%$ of that achieved in the absence of inhibitor (Table I). This reduction in growth rate was accompanied by a twofold increase in differential rate of $\alpha$-amylase, protease and ribonuclease formation (Table 1) compared with the tenfold increase observed during the transition from minimum to maximum rate of exoenzyme formation or the exponential to the post-exponential condition (Coleman, 1967). This partial effect was in turn accompanied by a twofold increase in 'nucleotide' pool size without change in the distribution of the individual components which retained the pattern described by Stormonth \& Coleman (1974). 


\section{DISCUSSION}

During the experiment, since growth took place and hence ribosomal RNA continued to be formed in the presence of $1 \mathrm{O}^{-5} \mathrm{M}$-streptolydigin, extensive release of RNA polymerase for increased exoenzyme mRNA synthesis would not be possible. However, since the rate of utilization of precursors diminished, it is possible that a higher 'steady state' nucleoside triphosphate level provided an increased substrate concentration for exoprotein mRNA formation (Coleman et al. 1974).

The fact that exoenzyme formation increased in proportion to the increase in 'nucleotide' pool size is consistent with the idea that exoenzyme mRNA synthesis depends on the concentration of mRNA precursor material.

These results provide the first evidence for a separation of the two parameters which, it has been suggested, are implicated in exoenzyme regulation, and provide additional evidence in support of the model proposed by Coleman et al. (1974).

D.A.S. thanks the Science Research Council for a Research Studentship.

\section{REFERENCES}

Cassani, G., Burgess, R. R., Goodman, H. M. \& Gold, L. (197I). Inhibition of RNA polymerase by streptolydigin. Nature New Biology 230, 197-200.

Coleman, G. (1967). Studies on the regulation of extracellular enzyme formation by Bacillus subtilis. Journal of General Microbiology 49, 421-431.

Coleman, G., Brown, S. \& Stormonth, D. A. (1974). A model for the regulation of Bacillus amyloliquefaciens extracellular enzyme biosynthesis. Journal of General Microbiology 8r, viii-ix.

Coleman, G. \& Ellotr, W. H. (1962). Studies on $\alpha$-amylase formation by Bacillus subtilis. Biochemical Journal 83, 256-263.

Coleman, G. \& Elliott, W. H. (1965). Extracellular ribonuclease formation in Bacillus subtilis and its stimulation by actinomycin D. Biochemical Journal 95, 699-706.

MAY, B. K. \& ElLIOTT, W. H. (I968). Characteristics of extracellular protease formation by Bacillus subtilis and its control by amino acid repression. Biochimica et biophysica acta 157, 607-615.

Stormonth, D. A. \& Coleman, G. (1972). A rapid and convenient method for determining the dry weight content of bacteria which show a tendency to form large aggregates. Journal of General Microbiology $7 \mathbf{r}$, 407-408.

Stormonth, D. A. \& Coleman, G. (1974). Cellular changes accompanying the transition from minimal to maximal rate of extracellular enzyme secretion by Bacillus amyloliquefaciens. Journal of Applied Bacteriology 37, 225-237.

WelKer, N. E. \& CAMPBelL, L. L. (1967). Unrelatedness of Bacillus amyloliquefaciens and Bacillus subtilis. Journal of Bacteriology 94, II $24-$ I I 30. 